\title{
Nahdlatul Ulama, Social Problem, and Preventive Principle
}

\author{
Ahmad Munif ${ }^{1}$, Ahmad Izzuddin ${ }^{2}$ \\ Sharia and Law Faculty, Universitas Islam Negeri Walisongo Semarang ${ }^{1,2}$
}

\{ahmadmunif@walisongo.ac.id¹,izzuddin@walisongo.ac.id²\}

\begin{abstract}
This paper tries to explain the preventive principle held by the Nahdlatul Ulama (NU). Principles used to address social problems that occur in society. The study focused on examining the results of the problems discussion (bahth al-masāil) of Lembaga Bahsul Masail (the Bahsul Masail Institute) for Pimpinan Wilayah NU Jawa Tengah (Regional Leadership of NU Central Java) for the period 2013-2018 related to the government law granting business permits and public frequencies in the perspective of figh. Content analysis is used with the sadd al-dharî'ah approach. The results of this study conclude, first, the application of the preventive principle in limiting the granting of business licenses to large entrepreneurs needs to be applied to protect small and medium scale economic entrepreneurs. Second, public broadcasting must be maintained in order to avoid elements of broadcast monopoly and broadcast content that does not benefit the public.
\end{abstract}

Keywords: Nahdlatul Ulama; Social Problems; Sadd Al-Dharî'ah

\section{Introduction}

Nahdlatul Ulama (NU) is one of the largest religious organizations in Indonesia. Founded in 1926, NU has always colored the life scene of the people in Indonesia. Not a few decisions or opinions issued provide solutions to complex problems facing society [1]. The opinion by $\mathrm{NU}$ is the result of a limited discussion in the bahsul masail (problems discussion) forum. This forum is organized by the central leadership and other leaders at the provincial and district or city levels [2].

Lembaga Baḥsul Masāil Pimpinan Wilayah NU Provinsi Jawa Tengah (The Baḥsul Masāil Institute Head of Central Java Province, hereinafter referred to as LBM PWNU) for the period 2013-2018 held a bahsul masāil regularly. No less than thirty opinions were generated by the LBM PWNU forum during that period. These answers or opinions are part of the development of fiqh among Indonesian Muslims, especially in the province of Central Java [3].

Among the existing opinions, there are two opinions that are interesting to study in depth, namely the opinion on the law of the government in granting business licenses and the frequency of the public from the perspective of fiqh. These two opinions use a preventive approach to attitude. The approach in the study of ușul fiqh (Islamic legal methodology) is closer to the study of sadd al-dharī'ah. This approach allows a law that was originally allowed 
to turn into something that is prohibited [4]. This prohibition is based on a strong suspicion of the negative possibilities that might arise if the legal act is carried out.

This paper will further examine how the implementation of the precautionary principle or sadd al-dharī'ah by the PWNU LBM in providing an opinion on the government law of granting business permits and public frequencies in the perspective of fiqh. The perspective of prevention needs to be encouraged to reduce the negative impact that is detrimental to the wider community on a policy or community activity.

\section{Sadd al-Dharī'ah in Islamic Studies}

\subsection{Definition of Sadd Dharī’ah}

Sadd al-dhari'ah consists of two words, sadd and al-dhari'ah. Sadd can be interpreted as al-hajru (hindering or hindering) and al-man'u (preventing or prohibiting) [5]. The word aldhari'ah is defined as; "An intermediary to arrive at something (to be aimed at)". There are also those who interpret al-dhari'ah with; "Something that leads to a case that prevents the mafsadah (destructive)." This second definition is commonly used by ushul scholars [6].

In contrast to the above definition, Ibn Qayyim al-Jauziyah, as stated by Imron, Fitriyati, and Na'mah, al-dhari' ${ }^{\prime}$ h is not only something that is seen as mafsadah, but also applies to everything that is considered manfa' $a h$. Therefore, there should be terms sadd al-dhari' $a$ h and fathu al-dharī'ah. Sadd al-dharī'ah means preventing things that are mafsadah and fathu aldhari'ah means encouraging or supporting things that are mașlahah (goodness) [5] [7][8]. Zuhaily by quoting al-Qarafiy also explains the possibility that al-dhari' $a h$ applies to sadd and fathu. In one law there are two elements, al-maqāșid and al-wasā'il. al-Maqāșid is the ultimate goal of an end which can be maslahah or mafsadah. While wasátil is a method or way to arrive at that final goal [6].

However, in terms of discussion of al-dhari'ah it is more appropriate to use the term sadd al-dharī'ah, preventing something that leads to mafsadah. Because if you use fathu aldhari' $\bar{l}^{\prime} a h$, it will mobilize things that support or support the realization of mașlahah. This kind of thing in the discussion of $u s u l$ is better known as muqadimah.

\subsection{The Method of Determining Sadd al-Dharī'ah}

Sadd al-dhari'sh can be determined and practiced by following and fulfilling the existing pillars. According to al-Burhani, there are at least three pillars in sadd al-dharī'ah [9];

a. Cases that are not originally prohibited or prohibited are in the category of immutable (mubāh). This pillar is an intermediary or wasilah. There are three possible circumstances or prerequisites; The case or act is intended for another case, The act is intended for the act itself; The act is the starting point for an intermediary.

b. Strong accusation (al-ifda '). This pillar is a kind of bridge between the initial treatment and the prohibited act. Its position is like 'ilah in the qiyās method.

c. Cases or actions that are forbidden, are prohibited (al-mutawasil 'alaih or al$m a m n \bar{u}$ ').

In Baroroh's study, by using Jasser Audah's approach, there are four possibilities that an mafsadah can be achieved or occur [10]; Mafsadah that will definitely happen; Mafsadah that will most likely happen; Mafsadah that might happen; A rare mafsadah. 
Therefore, changing of the law on actions from permissible to permissible or vice versa from permissible to being prohibited must consider the levels of the four possibilities above. One of the four categories is very likely to be attached to the action that the mukallaf is facing. Furthermore, Baroroh quotes Jasser Auda's three standards for determining the possibility of opening or closing an intermediary (al-dharī'ah) [10];

a. The level of ugliness of purpose. Actions that lead to this goal should be closed as much as possible.

b. Neutral Purpose. Actions that lead to this goal may be used or used.

c. The level of goodness of the goal. Acts leading to this goal must or must be exposed or used.

Meanwhile, establishes al-dharī'ah by looking at two possibilities [6];

a. The intention, motive, or purpose of someone doing something, whether it is aimed at what is lawful or what is haram. If there is an intention to address what is forbidden, even though it is something lawful, it must be prevented. Like people who get married in order to be just muhallil.

b. The result of an action, regardless of the intention or motive. If an act is strongly suspected to result in something mafsadah or prohibited, then the act should be prevented as much as possible.

\subsection{The Views of the Scholars on Sadd Dharī'ah}

Scholars had different opinions in accepting or commenting on sadd al-dharí'ah. As cited by Zuhaily, Imam Malik and Ahmad said that basically the concept of al-dharīah is the base of ușul fiqh. Meanwhile, Ibn Qayyim emphasized that sadd al-dhari'ah is a quarter of religion. As for Imam Shafi'i and Imam Abu Hanifah, in some cases they used sadd al-dharī'ah but denied their charity based on sadd al-dharī'ah. This is also the view of the Shi'ah and Ibn Hazm, who are more inclined to deny sadd al-dhari'ah [6].

Imam Shafi'i who accepted sadd al-dharī'ah on a certain point required the condition of his age so that the law based on this sadd al-dharī'ah could be used. According to Husain Hamid, as quoted by Mufid, the Hanafi's and Shafi'i's scholars are willing to use sadd al-dharī'ah if a large amount of adversity will occur, or at least it is strongly suspected and likely to occur [11].

Furthermore, Hanafi's and Shafi'i's scholars make intention as the main benchmark in establishing law. So, for example in the contract, what is seen is what the transacting parties intend and agree on. Meanwhile, the Maliki's and Hanbali's scholars made intentions and goals as benchmarks in establishing law. These standards of intention and purpose can still be manipulated with logic to establish the law. Meanwhile, the zahiri's scholars does not accept the role of logic at all in establishing sharia 'laws. Even though sadd al-dharī'ah requires logic in its operations. Therefore the zahiri's scholars absolutely rejects sadd al-dharī'ah [11].

\section{Implementation of Sadd al-Dharīah Perspective by LBM PWNU}

\subsection{LBM PWNU on Government Authority to Issue Business Licenses}


The opinion of LBM PWNU regarding the government's authority to grant business permits is linked to two studies. The first study is in the form of authority or ability to grant permission to the government. The second study is in the form of freedom to do business or economic activity. The two studies become interrelated, because within certain limits economic activities or efforts must get the green light from the government as the ruler. In Islam, economic activity must be dedicated to things that are in line with Islam. This can be traced, for example, from production objectives according to Islamic economics. These objectives include the following [12];

a. Economic activity is aimed at meeting human needs at a moderate level, not exaggeration.

b. Economic activities in order to find people's needs and how to fulfill them.

c. Economic activity can be in the form of preparing future needs, in the goods and services sector.

d. Economic activities that are intended to complement social activities which are indirectly a form of worship to Allah.

In the view of Ghofur, there are four main principles in terms of production as the basis for economic activity or business [13];

a. Islamic moral values are the main basis for production activities. The value refers to the priority scale outlined in the maqūssid al-sharī'ah (darūriy, hajiy, and tahsiniy). The priority scale referred to is the five basic human needs (religion, soul, mind, descent and property).

b. Social aspects of society are things that must be considered in production activities. Economic activities carried out as much as possible maintain the balance of the social and environmental environment.

c. Economic production activities are not only based on scarcity. In fact, there are more complex factors as to why scarcity occurs. Factors that humans may not be able to reach. It could be that scarcity holds millions of wisdoms that humans can learn.

d. Production activities in Islam are not only for the pursuit of maximum profit. In a broader view, that activity should be aimed at achieving happiness in this world and the hereafter.

Monzer Kahf, as quoted by Fauzia and Riyadi, emphasized the goal of maslahah in economic activities [14]. The goal should be;

a. Improving material conditions as well as preparation for the afterlife.

b. Profits from economic activities are also channeled into social aspects.

c. Maximizing the gifts given by God which humans often neglect.

Economic activities that adhere to the above principles are feasible. In the language of LBM PWNU, it does not include what is forbidden by religion. In response to the problems, LBM PWNU said that the government is welcome to give permits to businesses that do not fall into the category of religious granting Even so, the government actually has specific signs for issuing business permits. In the context of traditional market business activities and modern markets, the government has Peraturan Menteri Perdagangan (Permendag) Nomor 53/M-DAG/PER/12/2008 tentang Pedoman Penataan dan Pembinaan Pasar Tradisional, Pusat Perbelanjaan, dan Toko Modern (Regulation of the Minister of Trade Number 53/MDAG/PER/12/2008 concerning Guidelines for the Arrangement and Development of Traditional Markets, Shopping Centers and Modern Stores). 
There are many things the government should pay attention to in granting business permits for traditional or modern markets. Article 2 in this regulation states that the establishment must refer to a spatial planning arrangement and a detailed spatial plan. Followed by article 3 which requires an analysis of social conditions. This analysis concerns the existence of traditional markets and existing small and medium scale businesses. The regulations also set out the physical and operational requirements for modern market businesses. The existing articles are in order to ensure that traditional markets remain alive despite the presence of modern markets [3].

These rules are of course in line with the principles, goals and motivations of economic activity in Islam. When traditional markets and modern markets will stand and carry out their activities by referring to the provisions outlined in the existing regulations, it is indirectly in line with Islamic values. For this kind of thing, according to LBM PWNU, the government is okay to give business permits [3]. As the basic principle of muāmalah is al-ibăhah as long as there are no arguments or directions that lead to things that are forbidden. In the perspective of sadd dhari'ah, this is the first pillar, a case that is not originally forbidden or prohibited, in the category of mubāh. That is, the opening or establishment of a modern market business license is also an activity that will have a further impact, economic activity in the form of transactions of all types of services that will be provided by the modern market.

Furthermore, it is possible if there is a service or offer of similar goods between the modern market and the traditional market, and the modern market wins, gradually the traditional market will be left out. The tendency of traditional markets will be difficult to compete with modern markets. So it can be assumed that the modern market business license is the root of the destruction of transactions in traditional markets.

Another pillar of sadd dharī'ah, in the context of a modern market business license, leads to the most likely impact that will be received by traditional markets. LBM PWNU calls it a modern business unit, it is strongly suspected that it will cause losses to small or medium enterprises. According to LBM PWNU, the increasing number of modern business units will have an impact on economic disparities [3]. In the end, the third pillars of sadd dhari'ah will also be fulfilled, the economy will be controlled by large investors alone, a manifestation of the modern market [3]. In a different language, LBM PWNU said, there would be economic turnover between the rich only. This kind of thing is a form of wrong doing or persecution in economics which is prohibited in Islam.

Therefore, it is understood that carrying out economic activities is the right of every human being and the government as al-imām has the authority to grant permission. However, with the consideration of the sadd dhari'ah model, where economic activity by large investors in the form of modern markets is strongly suspected to provide compensation for other economic actors (small investors, small shops, traditional markets, etc.), economic activity by large investors must be prevented. The government has the authority to prevent this. So that the government's right to grant permissible permits also turns into a prohibition.

\subsection{Public Frequency in the Perspective of Fiqh}

The opinion of LBM PWNU regarding the use of public frequencies is in order to respond to public unrest over television shows that are not in accordance with the principles of public broadcasting. One of the main factors is due to the monopoly of broadcasting institutions. As can be seen in the answer to letter a, LBM PWNU emphasizes that broadcasting monopoly is not allowed. Either monopoly in the form of acquiring other public broadcasters or simply buying a portion of its shares [3]. 
LBM PWNU refers to Undang-Undang Nomor 32 tahun 2002 tentang Penyiaran (Law Number 32 of 2002 concerning Broadcasting). It should be noted that according to this law, broadcasting is actually aimed at "Strengthening national integration, building up the character and national identity that is faithful and cautious, educating the nation's life, advancing public welfare, in the framework of building an independent, democratic, just and prosperous society as well as growing the Indonesian broadcasting industry." (article 3).

All these goals within the framework of Islamic law are part of goodness and benefit. One of the efforts to ensure the achievement of these goodness and benefits is by preventing monopolistic practices of ownership and maintaining healthy competition in the broadcasting world (article 5 letter g). As Karman's study, monopolistic practices in the broadcasting world have a bad impact on society at large. Among them, the community does not have a bargaining position to get broadcast content that is intellectual and brings benefit to the community [15]. The alignments of monopolists to certain groups or groups make broadcast content unbalanced and tend to take sides. Something that is far from the value of character building and national identity.

In essence, monopolistic practices in the ownership and use of public frequencies are not prohibited. Because basically every person, individual, or group is free to own or control certain resources according to their abilities and capacities [16]. In Islamic law it is included in the category of mubāh. Or in the perspective of sadd al-dhari'ah, this provision is the first pillar, a case that is not originally prohibited or prohibited, is also in the category of mubāh [17]. Within this framework, the practice of controlling public frequencies is the starting point for other activities (one of the first pillar criteria in sadd al-dhari'ah). The most striking is the selection of various agenda items to be presented by the public. As a result of the limited control over public frequencies, as Karman's study above, broadcast content received by the public is also unbalanced. Broadcasting institutions also have certain tendencies, especially towards the largest shareholder in the ownership of the broadcasting company [18].

Furthermore, the strong accusation (al-ifda') is a bridge between the initial action and the forbidden action. This information can be seen in the LBM PWNU answer in letter $b$. It is strongly suspected that the monopoly on public frequencies will be used for private gain in their broadcast programs [3]. As explained by Rochim, the existence of broadcasting regulations is intended so that public broadcasting can work and operate as the basic objective of broadcasting, providing good information to the public. When this regulation is violated and tends to emphasize profit only, the public must pay dearly in the form of sacrificing character, personality, and independence [19].

Finally, the above behavior is strongly suspected to lead to actions that are prohibited in the third pillar of the stipulation of sadd al-dhari'ah, cases or actions that are forbidden, prohibited (al-mutawasil 'alaih or al-mamnū'). In the opinion of LBM PWNU, the use of public frequencies for personal gain, as reported in the problem description, is used to gossip about personal matters [3]. Even though it is very clear that the practice of gossiping is strictly prohibited in the Koran (QS al-Hujurat verse 12).

Thus, prohibiting the control of public frequencies in the form of ownership and broadcasting is prohibited according to LBM PWNU. This opinion is intended so that the interests of the wider community are not overridden by the interests of a certain group of people. Moreover, to avoid negative impacts in the form of not achieving education and public awareness through public frequencies. 


\section{Conlcusion}

Based on the description above it is known that LBM PWNU tries to provide a view of the problems faced by the community regarding permits to establish modern markets and public frequencies with preventive principle perspective. LBW PWNU uses a preventive approach or sadd al-dhari'ah on the possible negative impacts of the two problems. LBM PWNU is of the view that the government is prohibited from granting business permits for the establishment of modern markets. If possible, it will kill small and medium scale businesses in the vicinity. Also LBM PWNU considers harām to the monopoly of public frequencies used for personal gain that broadcast content is not good for the public.

\section{References}

[1] R. Bush, "Redefining" Political Islam" in Indonesia: Nahdlatul Ulama and Khittah'26," Stud. Islam., vol. 7, no. 2, pp. 59-86, 2000.

[2] A. M. Nasih, "Bahtsul Masail dan Problematikanya di Kalangan Masyarakat Muslim Tradisional,” Al-Qanun J. Pemikir. dan Pembaharuan Huk. Islam, vol. 12, no. 1, pp. 106-129, 2009.

[3] L. P. J. Tengah, Hasil Bahtsul Masail LBM PWNU Jawa Tengah 2013-2018. Semarang: LBM PWNU Jawa Tengah, 2018.

[4] and H. A. S. Rais, Isnawati, "The Polemic Prohibition of Wearing Veil in Perspective Al-qur' an and Sadd Al-dzari'ah," Talent Dev. Excell., vol. 12, pp. 2487-2495, 2020.

[5] U. Na'mah, "Ke-Hujjah-an Sadd al-Dhari'ah," usticia Islam. J. Kaji. Huk. dan Sos., vol. 12, no. 1, pp. 26-38, 2015.

[6] W. Al-Zuhailiy, Usul al-Fiqh al-Islamiy. Damaskus: Dar al-Fikr, 1986.

[7] A. Imron, "Menerapkan Hukum Islam yang Inovatif dengan Metode Sadd Dzari'ah," Qisti; J. Ilm. Ilmu Huk., vol. 4, no. 1, pp. 65-82, 2010.

[8] and Y. F. Gibtiah, Gibtiah, "Perubahan Sosial dan Pembaruan Hukum Islam Perspektif Sadd al-Dzari’ah,” Nurani J. Kaji. Syari’ah dan Masy., vol. 15, no. 2, pp. 101-114, 2015.

[9] M. H. Burhani, Sadd Dzari'ah fi al-Syari'ah al-Islamiyah. Damaskus: Dar al-Fikr, 1985.

[10] N. Baroroh, “Metamorfosis 'Illat Hukum' Dalam Sad Adz-Dzari'ah Dan Fath AdzDzariah (Sebuah Kajian Perbandingan),” Al-Mazahib J. Pemikir. Huk., vol. 5, no. 2, pp. 289-304, 2018.

[11] M. Mufid, Ushul Fiqh Ekonomi dan Keuangan Kontemporer: dari Teori ke Aplikasi. Jakarta: Kencana, 2016.

[12] N. R. Al Arif, Pengantar Ekonomi Syari'ah: Teori dan Praktik. Bandung: CV Pustaka Setia, 2015.

[13] A. Ghofur, Pengantar Ekonomi Syariah: Konsep Dasar, Paradigma, Pengembangan Ekonomi Syariah. Jakarta: Raja Grafindo Persada, 2017.

[14] and A. K. Riyadi, Ika Yunia Fauzia, Prinsip Dasar Ekonomi Islam Perspektif Maqāshid Syarīah. Jakarta: Prenadamedia Group, 2015.

[15] Karman, "Monopoli Kepemilikan Media \& Lenyapnya Hak Publik," Masy. Telemat. Dan Inf. J. Penelit. Teknol. Inf. dan Komun., vol. 5, no. 1, pp. 69-84, 2016. 
[16] E. Nurlaelawati, "Zakat and the Concept of Ownership in Islam: Yusuf Qaradawi's Perspective on Islamic Economics," Al-Jami'ah J. Islam. Stud., vol. 48, no. 2, pp. 365385, 2010.

[17] A. Hapsin, "How to Makae Islamic Law as The State Legal Policy of Indonesia: Constitutional and Sociological Arguments," Al-Ahkam, vol. 27, no. 2, pp. 139-156, 2017.

[18] D. Dwita, “Televisi dan Kepentingan Pemilik Modal dalam Perspektif Teori Ekonomi Politik Media,” J. Ipteks Terap., vol. 8, no. 4, pp. 252-261, 2014.

[19] M. Rochim, “Mengapa Kita Perlu Regulasi Penyiaran?," Mediat. J. Komun., vol. 8, no. 2, pp. 227-234, 2007. 